\title{
Adaptability and phenotypic stability for productive and reproductive traits in Nelore cattle
}

\author{
Mauricio Vargas da Silveira ${ }^{1}$ (D) Julio Cesar de Souza ${ }^{2,3^{*}}$ iD Paulo Bahiense Ferraz Filho ${ }^{2}$ \\ Luiz Otavio Campos da Silva ${ }^{4}$ Rosana Moreira da Silva Arruda \\ Carlos Henrique Cavallari Machado ${ }^{6}$ Mariana Alencar Pereira ${ }^{7}$
}

\author{
${ }^{1}$ Silveira Consultoria e Assessoria Pecuária, Aquidauana, MS, Brasil. \\ ${ }^{2}$ Universidade Federal de Mato Grosso do Sul (UFMS), Campo Grande, MS, Brasil. 79804-970. E-mail: julio.souza@ufms.br. ${ }^{*}$ Corresponding author. \\ ${ }^{3}$ Research Visitor University of Kent, England. \\ ${ }^{4}$ Embrapa Gado de Corte, Campo Grande, MS, Brasil. \\ ${ }^{5}$ Universidade Estadual de Mato Grosso do Sul (UEMS), Aquidauana, MS, Brasil. \\ ${ }^{6}$ Faculdades Associadas de Uberaba (FAZU), Uberaba, MG, Brasil. \\ ${ }^{7}$ Associação Brasileira de Criadores de Zebu, Uberaba, MG, Brasil.
}

\begin{abstract}
The present study aimed to estimate adaptability and stability parameters for Nellore bulls in 3 different regions. The traits analyzed included the weight of the animals raised in pasture at 420 days of age (W420) and at the age at first calving (AFC). The information used in this study was related to the phenotypic mean of the females which were the offspring of the top ten classified bulls based in one region. We used the methods proposed by Finlay \& Wilkinson (1963) \& Eberhart and Russell (1966) in order to evaluate the parameters of adaptability and stability of these animals. The averages estimated by the method of least squares were $243.91 \pm 34.90 \mathrm{~kg}$ and $1182.54 \pm 57.82$ days, respectively, for the traits W420 and AFC. Adaptability and stability parameters for the W420 characteristic showed that it is feasible to identify bulls with predictable behavior in different environments, and that these animals may generate progenies which may achieve above-average performance. Behavior of the 10 bulls analyzed in the different regions studied for the traits W420 and AFC showed that the herds and the regions influenced the performance of their progenies. The methods used allowed us to identify bulls with general adaptability, high stability, and better performances, which may be the most suitable to be used in herds in which the genetic merit of the cows and the environment where the progenies will be raised are both unknown.
\end{abstract}

Key words: genotype-environment interaction, parameters, weight, progeny.

\section{Adaptabilidade e estabilidade fenotípica para características produtiva e reprodutiva em} animais da raça Nelore

RESUMO: $O$ objetivo deste trabalho foi estimar parâmetros de adaptabilidade e estabilidade para touros da raça Nelore em três regiões diferentes. As características analisadas foram o peso aos 420 dias de idade (P420) e a idade ao primeiro parto (IPP) de animais criados em regime de pasto. As informações utilizadas no estudo foram referentes a média fenotípica das fêmeas, filhas dos dez melhores touros classificados com base em uma região. Para avaliar os parâmetros de adaptabilidade e a estabilidade foram utilizadas as metodologias propostas por FINLAY \& WILKINSON (1963) e EBERHART \& RUSSELL (1966). As médias estimadas pelos métodos dos quadrados mínimos foram de 243,91 $\pm 34,90 \mathrm{~kg}$ e 1182,54 157,82 dias, respectivamente, para as características P420 e IPP. Os parâmetros de adaptabilidade e estabilidade para a característica P420 mostraram que é possível identificar os touros com comportamento previsível nos diferentes ambientes e que poderão gerar progênies com desempenho acima da média. O comportamento dos dez touros analisados nas diferentes regioes estudadas para as características P420 e IPP, evidenciaram que os rebanhos e as regiões influenciaram na performance de suas progênies. Por meio das metodologias aplicadas é possível identificar touros com adaptabilidade geral, alta estabilidade e com melhores desempenhos, os quais seriam os mais adequados a se utilizar em rebanhos em que não se conhece o mérito genético das vacas e nem o ambiente onde serão criadas as progênies.

Palavras-chave: interação genótipo x ambiente, parâmetros, peso, progênie.

\section{INTRODUCTION}

There are a number of possibilities for a genotype to present different phenotypic expressions in distinct environments. Thus, it is important to evaluate the genotype-environment interaction which occurs in many livestock breeding programs (CRUZ \& REGAZZI, 1997). Based on the magnitude and significance of the interaction, the animal breeder should decide which procedures to apply in order to minimize and make the use of this correlation possible so that genetic gain is maximized. However, the genotype- environment interaction does not provide detailed information on 
the behavior of each genotype against environmental variations (Cruz \& Regazzi, 1997). Shmildt \& Cruz (2005) carried out research on plant breeding, and suggested two practical alternatives to minimize the effects of interaction between genotypes in different environments. The first one is based on the formation of strata that contained more homogeneous subregions, which can give subsidies to the disposal of environments in case of resource shortages. This is a situation that does not occur in animal breeding. The second alternative focused on the genotypes that presented wide adaptability and good stability.

The study of stability and adaptability may help identify genotypes of predictable behavior that can respond to environmental variations under specific or broad conditions. However, this information is fundamental at the time of the recommendation of the use of breeding genotypes (CRUZ \& REGAZZI, 1997; FALCONER \& MACKAY, 1996).

Several methods have been proposed for the evaluation of phenotypic stability and adaptability. Differences between these methods are based on biometric concepts and procedures to quantify the interaction (MOLINA, 2007). Lavoranti (2003) mentioneds that the main concepts for the term stability included the ability of an individual and/or population to produce minimal variations of phenotypes in different environments, potential to adjust their genotypic and phenotypic state to environmental fluctuations, and the ability of genotypes to show a highly predictable behavior according to the environmental stimulus. The present study aimed to estimate the adaptability and phenotypic stability of Nellore bulls using two methodologies for the characteristics of weight at 420 days of age (W420) and at the age of first calving (AFC) in different regions.

\section{MATERIALS AND METHODS}

Data from to the National Zootechnical Archive - Zebu breeds (ABCZ/Embrapa /MAPA partnership) was used in the present study. We used data from 2,520 Nelore females born between 1979 and 2008 and raised on pastures in three production regions of Mato Grosso do Sul, Central-West Brazil, which included Campo Grande-Dourados (R1), Alto Taquari-Bolsão (R2), and Pantanal Sul (R3). These regions were characterized and differentiated by Arruda and Sugai (1994) according to the production system, level of technology, quality and resource productivity, and breed of the cattle herd.

Initially, the expected differences in progenies (EDPs) were estimated for each trait individually and by region. Then the 3 files were joined into 1 file. A filter was used so that only the information from females whose parents had their offspring in both regions (at least 10 progenies per characteristic and per region) were maintained in the study. It should be emphasized that a reduction in the number of days for delivery was desired for the reproductive trait (AFC). Therefore, the best EDPs for these characteristics are negative which implies a decrease in the age at first calving (BOLIGON et al., 2008; BOLIGON et al., 2010).

Information used in the study of stability and adaptability were related to the phenotypic mean of the females from the 10 best bulls classified based on the R1 region. Therefore, not necessarily the same bulls that comprised the analyses of AFC are those of W420. The R1 was selected as the basis for comparison with the others due to the fact that in a previous study higher and lower averages were reported, as a result, for $\mathrm{W} 420$ and AFC in this region.

The dataset referring to the traits evaluated was submitted to analysis of variance in each region to verify the existence of genetic variability among the means of the progenies of the bulls tested in each region. The analysis of joint variance was performed with the purpose of detecting the interaction between the bulls and the regions. For such purpose, we constructed a data file containing environmental information (regions), genotype (bulls), and phenotypic values of the progenies for the evaluated characteristics (W420 and AFC).

Parametric and non-parametric methodologies were used to evaluate the parameters of adaptability and stability. The parametric method used consisted of a simple linear regression as proposed by Finlay \& Wilkinson (1963) and Eberhart \& Russell (1966). The difference between these methods allowed us to estimate the stability. The model proposed by Finlay \& Wilkinson (1963) consisteds of a simple linear regression analysis which allowed us to estimate the average performance of each bull in relation to the average of all bulls in each region (herd index). In the present study, the herd index involved the mean phenotypic value of the matrices and the Mendelian sample of the products within each region.

For the regression calculation, the following model was used:

$y_{i j}=I_{j}=\frac{1}{g} \sum_{i} Y_{i j}-\frac{1}{a g} Y_{. .} ;-\bar{\varepsilon}_{i j}$,

in which: $y_{i j}=$ mean of bull $i$ in herd $j$;

$\beta_{0 \mathrm{i}}=$ regression constant; $\beta_{1 \mathrm{i}}=$ linear regression coefficient; $X_{i}=$ herd index coded by:

$I_{j}=\frac{1}{g} \sum_{i} Y_{i j}-\frac{1}{a g} Y_{. .}$ 
$\delta_{\mathrm{ij}}=$ regression deviation; = mean experimental error. Therefore, it was noted that: $\Sigma_{-} i I_{-} j=0$, and with the use of this index, we have: $\beta_{-} 0 \mathrm{i}^{-} \mathrm{y}_{-} \mathrm{i}=$ mean of bull $\mathrm{i}$. For the estimation of the parameters of stability and adaptability, the following model was used:

$y_{i j}=\beta_{0 i}+\beta_{1 i} X_{j}+\Psi_{i j}\left(\Psi_{i j}=\delta+\bar{\varepsilon}_{i j}\right)$;

matricially written:

$\mathrm{Y}=\mathrm{X} \beta+\Psi$, for each $\mathrm{i}$. Therefore, we have:

Y: vector $(\mathrm{a} \times 1)$ of averages of bull $i$ in different regions; $X$ : matrix ( $\mathrm{axp}$ ) in which $\mathrm{p}$ is the number of parameters to be estimated; $\beta$ : parameter vector ( $\mathrm{p} \times 1)$; $\Psi$ : error vector (a $\mathrm{x} 1)$.

The estimates of the adaptability parameters were interpreted on the basis of the linear regression coefficients $\left(\beta_{1 \mathrm{i}}\right)$ and the means $\left(\beta_{0 \mathrm{i}}\right)$ which measure the responses of a bull $i$, the variation of the regions. Bulls with regression coefficients close to $1\left(\beta_{1 \mathrm{i}}=1\right)$ are considered of average stability. If associated with high yields, $\left(\beta_{00}\right)$ are considered of broad adaptability. If $\left(\beta_{1 \mathrm{i}}>1\right)$, it indicated below-average stability and specific adaptability to herds in which the genetic means of the matrices are highest. Otherwise, $\left(\beta_{1 \mathrm{i}}<1\right)$, bulls presented above-average stability and specific adaptation to herds in which the genetic mean of the matrices is lower (CRUZ \& REGAZZI, 1997).

Considering the method proposed by Finlay \& Wilkinson (1963) but in order to improve this method, Eberhart \& Russell (1966) included the variance of the regression deviation as an additional stability parameter (CRUZ \& CARNEIRO, 2003). In this method, the ideal is that the animal presents high average productivity, and . A bull is stable when the regression deviations showed a variance equal to zero . Coefficient of determination is defined as the auxiliary stability measure $\left(\mathrm{R}^{2}\right)$ of each bull, and was also used to quantify whether the proportion of the phenotypic variation of each bull is explained by linear regression. The ideal is to obtain a coefficient of determination equal to $1\left(\mathrm{R}^{2}=1\right)$, or close to $100 \%$.

In order to estimate the adaptability and stability of regression coefficients $\left(b_{i}\right)$ and stability parameters, the variance analysis method was used from the mean square of the regression deviation of each bull $\left(\mathrm{QMD}_{\mathrm{i}}\right)$ and of the mean square of the residue, i.e.:

$\hat{\alpha}_{d i}^{2}=\frac{Q M D_{i}-Q M R}{r}$,

in which: $\mathrm{QMD}_{\mathrm{i}}$ : average squared deviation (mean square regression) of bull i;

QMR: mean square of residuals; $r$ : number of repetitions.

The hypothesis was evaluated by the F statistic, provided by
$F=\frac{Q M D_{i}}{Q M R}$

and associated with a significance level $\alpha$ and a-1 and $m$ degrees of freedom, $m$ being the number of degrees of freedom of the residuals obtained in the joint analysis. The hypothesis that any regression coefficient does not differ from $1\left(b_{i}=1\right)$ was evaluated by the $t$ test. The hypothesis that the regression deviations of each bull did not differ from zero was verified by the $F$ test (MARCAL et al., 2014).

We used the non-parametric method proposed by Huehn (1990). This researcher assessed the genotypic material through the S1, S2, and S3 statistics based on the classification of genotypes in different environments. Genotype with S1, S2, and S3 equal or close to zero are considered of maximum stability. the following:

Formulas used for the calculations were

$\mathrm{S}_{1 \mathrm{i}}$ : mean absolute differences between classifications of genotype $\mathrm{i}$ in the environments, provided by:

$S_{1 i}=\frac{\sum\left|r_{i j}-r_{i j \prime}\right|}{a(a-1) / 2}$

in which, $r_{i j}$ : classification of genotype $i$ in environment $\mathrm{j}$; a: number of environments;

$\mathrm{S}_{2 \mathrm{i}}$ : variance of genotype $\mathrm{i}$ classifications in the environments, provided by:

$S_{2 i}=\frac{\sum\left(r_{i j}-\bar{r}_{i}\right)^{2}}{a-1}$

in which:

$r_{i}=\frac{\Sigma r_{i j}}{a}$

$\mathrm{S}_{31}$ : sum of the absolute deviations of each classification in relation to the average of the classifications, provided by:

$S_{3 i}=\frac{\Sigma\left|r_{i j}-\bar{r}_{i}\right|}{\bar{r}_{i}}$

The SAS (Statistical Analysis System) software was used in analyses of joint variance and database manipulation. For the analyses of adaptability and stability, we used the software Genes - computational application in genetics and statistics, Windows version (CRUZ, 2001) was used.

\section{RESULTS AND DISCUSSION}

Results of the analyses of the combined variance indicated that all sources of variation were significant for the W420 $(\mathrm{P}<0.05)$ by the $F$ test. In contrast, for the AFC trait, the effects of region and bull-region were both not significant $(\mathrm{P}>0,05)$. 
These results demonstrated the importance to assess the adaptability and stability parameters of the bulls since the significance of the bullherd interaction does not specify the performance of the animals in different environments. The averages estimated by the least squares methods were $243.91 \pm 34.90 \mathrm{~kg}$ and $1182.54 \pm 157.82$ days, respectively, for the characteristics $\mathrm{W} 420$ and AFC. Wenceslau et al. (2012) and Silveira et al. (2014) conducted studies on Nellore cattle and reported similar results: $243.29 \pm 42.09 \mathrm{~kg}$ and $235.80 \pm 40.78$ $\mathrm{kg}$, respectively, for W420. The mean for AFC in our study was similar to those reported by Boligon et al. (2010) and Boligon \& Albuquerque (2011): 1050.00 and 1056.00 days, respectively, for Nelore females. In contrast, Bresolin et al. (2015) analyzed information of 71,101 Nelore females and reported a mean of 1370 days for AFC.

Based on the phenotypic average of the progenies, the herd index of the region was generated. For W420, the mean of the R1 region was the highest one and, as a result, the environmental index was positive. Therefore, it can be stated that the $\mathrm{R} 1$ region is favorable whereas the $\mathrm{R} 2$ and $\mathrm{R} 3$ regions are unfavorable to the performance of the W420 characteristic. For the AFC trait, a decrease in the days for the delivery is sought after. Therefore, the ideal ones are the animals of lower ages at the first calving. In this case, the $\mathrm{R} 1$ and $\mathrm{R} 2$ regions were considered a favorable environmental index whereas the R3 region had an unfavorable environmental index (Table 1).

Table 1 - Estimates of mean progenies of bulls and herd index of the region $(\mathrm{Ij})$, according to the method proposed by Finlay and Wilkinson (1963) and Eberhart and Russell (1966) for the weight characteristics at 420 days of age (W420) and age at first calving (AFC) in Nellore females.

\begin{tabular}{llccc}
\hline & & & & \\
& & & & \\
\hline Region & Mean & $(\mathrm{Ij})$ & Mean & $(\mathrm{Ij})$ \\
R1 & 249.62 & 7.80 & 1178.61 & -9.65 \\
R2 & 235.31 & -6.51 & 1188.10 & -0.16 \\
R3 & 240.53 & -1.29 & 1198.07 & 9.81 \\
\hline
\end{tabular}

R1: Campo Grande - Dourados; R2: Alto Taquari - Bolsão; R3: Pantanal Sul.
The discrepancy associated with the regions considered unfavorable may be explained by the fact that the matrices may present lower EDPs, which may have directly interfered with the progeny response of a particular bull. Thus, bulls that were able to correct this factor and have progenies with better performance were considered adapted to the herd which is a desirable breeding trait. In the herds of the regions considered favorable, the averages of the EDPs of the matrices were superior, which improved the average of the EDPs of the progenies; and allowed the identiication of bulls with better performance in herds of higher genetic value (MARÇAL et al., 2014).

Results (Table 2), according to the method published by Finlay \& Wilkinson (1963) and Eberhart \& Russell (1966), indicated differences in the phenotypic means $\left(\beta_{\mathrm{o}}\right)$ of progenies of the bulls in the regions for the traits W420, ranging between 218.79 and $268.03 \mathrm{~kg}$. Among the 10 bulls evaluated, 7 had productivity above the general average $(241.82 \mathrm{~kg})$.

The adaptability parameter $\left(\beta_{1 \mathrm{i}}\right)$ values of each bull were subjected to the $t$ test. Using this test, we reported that only Bull 10 had the value of the coefficient $\beta_{1 \mathrm{i}} \neq 1$. Since the value reported for this bull was greater than $1\left(\beta_{1 i}>1\right)$, it was defined as suitable for favorable herds, i.e. adapted to herds in which the average of matrices are higher. The other bulls ( 1 to 9 ) were classified as having general or wide adaptability as they have the coefficient $\beta_{1 \mathrm{i}}=1$ (Table 2).

As for the parameter stability $\left(\alpha^{2}{ }_{\mathrm{di}}\right)$, the estimated values for each bull were subjected to significance testing. By using this test, we reported that Bulls 1, 2, 3, 5, 6, and 9 presented values of $\alpha^{2}{ }_{\mathrm{di}}=0$. In addition, the values of the coefficient of determination $\left(\mathrm{R}^{2}\right)$ were considered high (above $50 \%$ ) which allowed us to classify these bulls as high stability breeding animals. The other bulls (4, 7 , and 8 to 10 ) had the coefficient of $\alpha^{2}{ }_{\text {di }} \neq 0$ and were therefore, defined as breeding low stability (Table 2).

Based on the discussion about the adaptability and stability parameters for the characteristic W420, it is possible to identify bulls with predictable behavior in different environments that may generate progenies with above average 
Table 2. Estimates of the adaptability parameters $\left(\beta_{\mathrm{oi}}, \beta_{1 \mathrm{i}}\right)$ and stability $\left(\alpha^{2} \mathrm{di}\right)$ and coefficient of determination $\left(\mathrm{R}^{2}\right)$ of the ten bulls evaluated for the 420 day age characteristic (W420), according to the methodology of Finlay and Wilkinson (1963) and Eberhart and Russell (1966).

\begin{tabular}{lcccc}
\hline Bulls & Boi $(\mathrm{Kg})$ & $\beta 1 \mathrm{i}$ & $\alpha^{2} \mathrm{di}$ & $\mathrm{R}(\%)$ \\
\hline 1 & 245.90 & $0.33 \mathrm{~ns}$ & $-8.79 \mathrm{~ns}$ & 54,12 \\
\hline 2 & 249.53 & $0.78 \mathrm{~ns}$ & $25.73 \mathrm{~ns}$ & $5.53 \mathrm{~ns}$ \\
\hline 3 & 242.57 & $0.67 \mathrm{~ns}$ & $69.28^{*}$ & 67.85 \\
\hline 5 & 242.14 & $1.33 \mathrm{~ns}$ & $-10.74 \mathrm{~ns}$ & 64.16 \\
\hline 6 & 243.72 & $0.63 \mathrm{~ns}$ & $-11.74 \mathrm{~ns}$ & 62.61 \\
\hline 7 & 232.42 & $0.33 \mathrm{~ns}$ & $654.31 * *$ & 62.36 \\
\hline 9 & 268.03 & $1.36 \mathrm{~ns}$ & $109.74 * *$ \\
\hline General mean & 247.22 & $1.44 \mathrm{~ns}$ & $27.86 \mathrm{~ns}$ \\
\hline
\end{tabular}

$\mathrm{ns}=$ non-significant result $(\mathrm{P}>0.05)$ according to the $\mathrm{t}$ test; ++ significant results at $5 \%$ probability by the $\mathrm{t}$ test; ${ }^{* *}$ significant result at the $5 \%$ probability level $(\mathrm{P}<0.05)$ by the $\mathrm{F}$ test.

performance. Thus, Bulls 1, 2, 3, and 5 were classified as having general or wide adaptability, high stability, and an above average performance (Table 2).

The non-parametric method proposed by Huehn (1990) made possible to estimate the stability through the expressions $\mathrm{S}_{1}, \mathrm{~S}_{2}$ e $\mathrm{S}_{3}$. It was observed that for the expressions $\mathrm{S}_{1}$ and $\mathrm{S}_{2}$, Bulls $3,6,7$, and 10 were those that had lower values. As for the expression $\mathrm{S}_{3}$, Bulls 3, 6, 9, and 10 had higher values (Table 3 ) considering the fact that the weight and body condition are crucial factors for the development of females.

Table 3 - Stability estimates according to the method proposed by Huenh (1990) for the 10 bulls evaluated for the characteristic weight at 420 days of age (W420).

\begin{tabular}{lcccc}
\hline Bull & S1 & S2 & S3 & ṛi \\
\hline 1 & 1.33 & 1.00 & 0.50 & 4.00 \\
2 & 1.33 & 1.33 & 1.14 & 2.33 \\
3 & 0.67 & 0.33 & 0.25 & 5.33 \\
4 & 2.00 & 2.33 & 0.59 & 5.67 \\
5 & 3.33 & 8.33 & 1.25 & 5.33 \\
6 & 0.67 & 0.33 & 0.16 & 8.33 \\
7 & 0.67 & 0.33 & 1.00 & 1.33 \\
\hline 9 & 2.67 & 4.00 & 1.00 & 4.00 \\
10 & 1.33 & 1.00 & 0.22 & 9.00 \\
\hline
\end{tabular}

$\overline{\mathrm{r}}_{\mathrm{i}}$ : mean of the classifications or average of the positions of the phenotypes in the different environments; S1: mean absolute differences between classifications of genotype $i$ in environments; $S_{2}$ : variance of genotype i classifications in environments; $S_{3}$ : sum of the absolute deviations of each classification from the average of the classifications. 
Bulls that produced an offspring with a W420 above average were the ones sought after. Bull 7 was the one that presented a more stable behavior, and had a good mean rating in all environments which can be confirmed by expression $r_{1}$ (Table 3 ). These findings indicated that in this case there was no agreement between the methods used. This result may be explained by the fact that the method proposed by Finlay \& Wilkinson (1963) and Eberhart \& Russell (1966) takes the regression deviations into account.

For the traits AFC, regions and bulls with lower means are considered the best ones. Thus, the analysis (see Table 4) indicated that the phenotypic means $\left(\beta_{\mathrm{oi}}\right)$ of the progeny of the bulls in the regions ranged between 1148,57 and 1243,91 days. The productivity of 5 of the 10 bulls evaluated was below the general average (1188,26 days).

For the parameter adaptability $\left(\beta_{11}\right)$, the values of each bull were subjected to the $t$ test. We reported that only Bull 3 presented a value of the coefficient $\beta_{1 \mathrm{i}} \neq 1$. Since the value reported for this bull was less than $1\left(\beta_{1 \mathrm{i}}<1\right)$, this bull was defined as suitable for unfavorable herds, i.e. it presented best performance in herds in which the genetic merit of the matrices were worse for the feature studied. The other bulls $(1,2,4,5,6,11,12,13$, and 14) had the coefficient $\beta_{1 \mathrm{i}}=1$ and were classified as animals of wide or general adaptability (Table 4).

As to the stability parameter $\left(\alpha_{\mathrm{di}}^{2}\right)$ the estimated values for each bull were subjected to the test of significance. Using this test, we reported that Bulls 1, 2, 3, 4, 5, 6, 11, 13, and 14 presented values $\alpha_{\mathrm{di}}^{2}=0$. Besides, the values of the coefficient of determination $\left(\mathrm{R}^{2}\right)$ were considered high (above $50 \%$ ), which allowed us to classify these animals as high stability breeding bulls. Only Bull 12 was regarded as having low stability since it has the coefficient $\alpha_{\mathrm{di}}^{2} \neq 0$ (Table 4).

In view of the results for the $\mathrm{AFC}$ characteristic, it is possible to identify the bulls with predictable behavior in different environments and that can generate progenies with better performances, i.e. lower ages at first calving (below average). Bulls 1 , 4,5 , and 14 were classified as having general or broad adaptability, high stability, and better performance to produce a precocious offspring for AFC compared to other animals from the same herd.

As for the non-parametric methodology proposed by Huehn (1990) for the AFC characteristic, values obtained for $\mathrm{S}_{1}, \mathrm{~S}_{2}$ and $\mathrm{S}_{3}$ were analyzed. Bulls $1,4,5,11$, and 14 were the ones that had the lowest values and, therefore, were considered the ones of most interest. We noted that bulls 1 and 14 were the ones that presented a more stable behavior and with average good classification in all the environments (Table 5). For the AFC characteristic, there were partial agreement in the methods used for the analyses of adaptability and stability. However, these are tools that may help with the programs of genetic improvement of cattle and cattle selection.

Marçal et al. (2014) used the method published by Finlay \& Wilkinson (1963) and

Table 4 - Estimates of the adaptability parameters $\left(\beta_{\mathrm{oi}}, \beta_{1 \mathrm{i}}\right)$ and stability $\left(\alpha_{\mathrm{di}}^{2}\right)$ and coefficient of determination $\left(\mathrm{R}^{2}\right)$ of 10 bulls evaluated for the characteristic age at first calving (AFC), according to Finlay and Wilkinson (1963) and Eberhart and Russell (1966).

\begin{tabular}{|c|c|c|c|c|}
\hline Bulls & $\beta$ oi & (days) $\beta 1 \mathrm{i}$ & $\alpha^{2} \mathrm{di}$ & R2 (\%) \\
\hline 1 & 1154.35 & $1.29 \mathrm{~ns}$ & $482.18 \mathrm{~ns}$ & 26.77 \\
\hline 2 & 1207.72 & $3.30 \mathrm{~ns}$ & $-329.43 n s$ & 97.73 \\
\hline 3 & 1148.57 & $-2.99++$ & $85.07 \mathrm{~ns}$ & 78.60 \\
\hline 4 & 1183.35 & $0.74 \mathrm{~ns}$ & $-359.39 n s$ & 85.17 \\
\hline 5 & 1184.27 & $0.94 \mathrm{~ns}$ & $-6.78 n s$ & 31.01 \\
\hline 6 & 1198.35 & $1.32 \mathrm{~ns}$ & $190.31 \mathrm{~ns}$ & 36.64 \\
\hline 11 & 1199.68 & $1.76 \mathrm{~ns}$ & $-195.17 \mathrm{~ns}$ & 76.21 \\
\hline 12 & 1243.91 & $3.58 \mathrm{~ns}$ & $1208.62^{* *}$ & 60.54 \\
\hline 13 & 1208.74 & $-1.22 \mathrm{~ns}$ & $-151.65 n s$ & 55.67 \\
\hline 14 & 1153.63 & $1.29 \mathrm{~ns}$ & $-315.33 n s$ & 83.61 \\
\hline General mean & 1188.26 & & & \\
\hline
\end{tabular}

$\mathrm{ns}=$ non-significant result $(\mathrm{P}>0.05)$ according to the test $\mathrm{t} ;++$ significant results at $5 \%$ probability by the $\mathrm{t}$ test; ${ }^{* *}$ significant result at the $5 \%$ probability level $(\mathrm{P}<0.05)$ by the $\mathrm{F}$ test. 
Table 5 - Stability estimates according to the method proposed by Huenh (1990) for the 10 bulls evaluated for the characteristic age at first calving (AFC).

\begin{tabular}{|c|c|c|c|c|}
\hline Bull & $\mathrm{S} 1$ & $\mathrm{~S} 2$ & S3 & ṛ̣ \\
\hline 1 & 1.33 & 1.00 & 0.22 & 9.00 \\
\hline 2 & 3.33 & 7.00 & 1.50 & 4.00 \\
\hline 3 & 4.67 & 14.33 & 1.18 & 7.33 \\
\hline 4 & 0.67 & 0.33 & 0.21 & 6.33 \\
\hline 5 & 1.33 & 1.00 & 0.29 & 7.00 \\
\hline 6 & 2.00 & 2.33 & 0.91 & 3.67 \\
\hline 11 & 1.33 & 1.00 & 0.50 & 4.00 \\
\hline 12 & 2.00 & 3.00 & 2.00 & 2.00 \\
\hline 13 & 2.67 & 4.33 & 1.75 & 2.67 \\
\hline 14 & 1.33 & 1.00 & 0.22 & 9.00 \\
\hline
\end{tabular}

$\overline{\mathrm{r}}_{\mathrm{i}}$ : mean of the classifications or average of the positions of the phenotypes in the different environments; $\mathrm{S}_{1}$ : mean of absolute differences between genotype i classifications in environments; $\mathrm{S}_{2}$ : variance of classifications of genotype $\mathrm{i}$ in environments; $\mathrm{S}_{3}$ : sum of the absolute deviations of each classification from the mean of the classifications.

Eberhart \& Russell (1966) to estimate the parameters of adaptability and stability. These authors observed that, for the weight characteristic in animals from the Tabapuã breed, there are differences in the performance of the herds at 120 days of age. They identified perfectly adapted and stable bulls, bulls with general adaptation, and bulls with specific adaptation to both favorable and unfavorable environments. Barros et. al. (2006) use the same method to analyze records for weight at weaning, weight at 12 months, and weight gain up to 160 days post weaning. These authors demonstrated that the method used was efficient in differentiating the behavior of genotypic combinations within each environment.

\section{CONCLUSION}

The behavior of the 10 bulls analyzed in the different regions studied for the W420 and AFC characteristics, showed that both herds and regions influenced the performance of their progenies.

Using the methods aforementioned, it is possible to identify bulls with general adaptability, high stability, and with better performance, which would be the most suitable to be used in herds in which the genetic merit of the matrices is unknown and the environment where the progenies will be created.

Results obtained using these methods to analyze adaptability and stability indicated that for the W420 characteristic there was no agreement among the methods. However, there was parcial agreement for AFC.

\section{DECLARATION \\ OF \\ CONFLICTING INTERESTS}

The authors declare no conflicts of interests.

\section{AUTHORS' CONTRIBUITIONS}

The authors contributed equally to the manuscript.

\section{ACKNOWLEDGEMENTS}

Fundação de Apoio ao Desenvolvimento do Ensino, Ciência e Tecnologia do Estafdo do Mato Grosso do Sul (FUNDECT) and Coordenação de Aperfeiçoamento de Pessoal de Nível Superior (CAPES) for the support.

\section{REFERENCES}

ARRUDA, Z, J.; SUGAI, Y. Regionalização da pecuária bovina no Brasil. Campo Grande: EMBRAPA-CNPGC, 1994. 144p.

BARROS, J. B. G., et al. Estimativas e estabilidade fenotítica em características produtivas em bovinos de corte mestiços criados em diferentes ambientes. Arquivo Brasileiro de Medicina Veterinária e Zootecnia, v.58, p.590-598, 2006.

BOLIGON, A. A.; ALBUQUERQUE, L. G. Genetic parameters and relationships of heifer pregnancy and age at first calving with weight gain, yearling and mature weight in Nelore cattle. Livestock Science, v.141, p.12-16, 2011. 
BOLIGON, A. A., et al. Study of relations among age at first calving, average weight gains and weights from weaning to maturity in Nellore cattle. Revista Brasileira Zootecnia, v.39, p.746-751, 2010.

BOLIGON, A. A., et al. Parâmetros genéticos para idade ao primeiro parto estimados por diferentes modelos para rebanhos da raça Nelore. Ciência Rural, v.38, p.432-436, 2008.

BRESOLIN, T., et al. Components of (co)variance for age at first and second calving of nellore females raised in southern Brazil. Ciência Animal Brasileira, v.16, p.474-480, 2015.

CRUZ, C. D. Programa Genes: versão Windows - Aplicativo computacional em genética e estatística. Viçosa: UFV, 2001. 648p.

CRUZ, C. D.; CARNEIRO, P. C. S. Modelos biométricos aplicados ao melhoramento genético. Viçosa, UFV, 2003.585p.

CRUZ, C. D.; REGAZZI, A. J. Modelos biométricos aplicados ao melhoramento genético. Viçosa: UFV, 1997. 390p.

EBERHART, S. A.; RUSSELL, W. A. Stability parameters for comparing varieties. Crop. Science, v.6, p.36-40, 1966.

FALCONER, D. S., MACKAY, T. F. C. Introduction to quantitative genetics. 4ed. England: Longman, 1996. 463p.

FINLAY, K. W.; WILKINSON, G. N. The analysis of adaptation in a plant breeding programme. Aus. J. Agric. Res., v.14, p.742754, 1963.
HUEHN, M. Nonparametric measures of phenotypic stability. Part I: theory. Euphytica. v.47, p.189-194, 1990.

LAVORANTI, O. J. Estabilidade e adaptabilidade fenotípica através da reamostragem "bootstrap" no modelo AMMI. 2003. 166f. Tese (Doutorado em Estatística e Experimentação Agronômica) - Escola Superior de Agricultura "Luiz de Queiroz", Universidade de São Paulo, Piracicaba.

MARCAL, M. F., et al. Estabilidade e adaptabilidade de touros Tabapuã para característica de desempenho em função do índice de rebanhos. Arquivo Brasileiro de Medicina Veterinária e Zootecnia, v.66, p.195-202, 2014.

MOLINA, L. M. R. Um estudo sobre métodos estatísticos na avaliação de interação genótipo $x$ ambiente em linhagens de arroz (Oryza sativa L). 2007. 68f. Dissertação (Mestrado em Agronomia) - Faculdade de Ciências Agrárias e Veterinárias UNESP, Jaboticabal.

SCHMILDT, E. R.; CRUZ, C. D. Análise da adaptabilidade e estabilidade do milho pelos métodos de Eberhart \& Russell (1966) e de Annicchiarico (1992). Revista Ceres, v. 52, p.45-58, 2005.

SILVEIRA, M. V., et al. Interação genótipo x ambiente sobre características produtivas e reprodutivas de fêmeas Nelore. Archivos de Zootecnia, v.63, p.223-226, 2014.

WENCESLAU, R. R, et al. A. Estimativas de componentes de (co) variância para peso e escores visuais de conformação frigorífica em bovinos Nelore. Arquivo Brasileiro de Medicina Veterinária e Zootecnia, v.64, p.443-449, 2012. 


\section{Erratum}

In the article "Adaptability and phenotypic stability for productive and reproductive traits in Nelore cattle" published in Ciência Rural, volume 49, number 3, DOI http://dx.doi.org/10.1590/0103-8478cr20180327.

Where we read:

Universidade Estadual de Mato Grosso do Sul (UFMS), Campo Grande, MS, Brasil. 79804-970. E-mail: julio.souza@ufms.br. *Corresponding author.

Read:

Universidade Federal de Mato Grosso do Sul (UFMS), Campo Grande, MS, Brasil. 79804-970. E-mail: julio.souza@ufms.br. *Corresponding author. 